\title{
Phosphorus cardanol: chemical characterization and thermal stability
}

Fósforo cardanol: caracterização química e estabilidade térmica

\author{
M. A. S. Rios ${ }^{1 *}$, F. S. C. L. Batista ${ }^{2}$, F. A. M. Sales ${ }^{3}$, S. E. Mazzetto ${ }^{4}$ \\ ${ }^{a}$ Grupo de Inovações Tecnológicas e Especialidades Químicas, Universidade Federal do Ceará, \\ ${ }^{1}$ Departamento de Engenharia Mecânica/Grupo de Inovações Tecnológicas e Especialidades Químicas/Centro de \\ Tecnologia, Universidade Federal do Ceará, 60.440-554, Fortaleza-Ceará, Brasil \\ ${ }^{2}$ Departamento de Química/ Grupo de Inovações Tecnológicas e Especialidades Químicas/Centro de Ciências, \\ Universidade Federal do Piauí, 64.049-550, Teresina-Piauí, Brasil \\ ${ }^{3}$ Instituto Federal do Ceará, 63.503-790, Iguatu-Ceará, Brasil \\ ${ }^{4}$ Departamento de Química Orgânica e Inorgânica/ Laboratório de Produtos e Tecnologia em Processos LPT/Centro \\ de Ciências, Universidade Federal do Piauí, 60.455-760, Fortaleza-Ceará, Brasil
}

*alexsandrarios@ufc.br

(Recebido em 07 de setembro de 2015; aceito em 22 de fevereiro de 2016)

\begin{abstract}
Devido à grande utilização do cardanol para o desenvolvimento de novos aditivos, o presente trabalho tem como objetivos apresentar a caracterização química do fósforo cardanol, a qual foi verificada utilizando-se FTIR e técnicas termoanalíticas (TG/DSC/DTA) e, a avaliação antioxidante do composto em um óleo lubrificante de base naftênica. Neste trabalho, os autores incluíram também o estudo térmico do fósforo cardanol por aquecimento em estufa, com monitoramento das alterações em FTIR. De acordo com os resultados, o fósforo cardanol apresentou boa estabilidade térmica quando comparado a outros ésteres de fosfato de mesma classe e, não apresentou alterações antes e após aquecimento a $120^{\circ} \mathrm{C}$, sob atmosfera de ar. Desta forma, o composto de fósforo obtido a partir do cardanol apresenta potencial de aplicação, como aditivo, em óleos lubrificantes e produtos petroquímicos do mesmo segmento.
\end{abstract}

Palavras-chave: LCC, oxidação, estabilidade térmica

Due to the wide use of the cardanol to develop new additives, this study presents the chemical characterization of phosphorus cardanol using FTIR and Thermoanalytical techniques (TG / DSC / DTA), and the evaluation of the antioxidant potentiality of compound when added to a lubricating oil. In this paper, the authors also included the thermal study of phosphorus cardanol by heating in an oven, monitoring changes in FTIR. According to results, the phosphorus cardanol showed good thermal stability when compared with other compounds of the same class "phosphate esters" and showed no changes before and after heating at $120^{\circ} \mathrm{C}$, under air atmosphere. Thus, the phosphorus compound derived from cardanol has potential application as additive for lubricating oils and petrochemicals of the same segment.

Keywords: CNSL, oxidation, thermal stability

\section{INTRODUCTION}

Cashew Nut Shell Liquid (CNSL) and its derivatives are an important group of molecules, which play a fundamental role in organic chemistry [1-4]. They have potent antioxidant activity in several industrial areas such as: fuels and biofuels; tribology; polymers [5,6]; rubbers [7-10] and can be used in the biological industry too as antibacterial, anti-fungal and anti-tumor [11,12].

Due to chemical versatility of these compounds and increasing concern with the environmental legislation on the maintenance of greenness in industrial processes led us to develop a method using a reagent that is less hazardous and non-toxic to the environment $[13,14]$. In this context, in the last years, the CNSL has gained importance in the development of sustainable chemistry [15] as a raw material for new primary and secondary antioxidants, flame-retardants, porphyrins, composites and biopolymers [16-19].

CNSL is constituted of anacardic acid, cardanol and cardols, which are alkyl-substituted phenolic compounds, Figure $1[13,20]$. In accordance with the literature, the quantity and quality 
of constituents vary with the method of extraction. The CNSL extracted from the shells by mechanical expulsion contain a mixture of anacardic acid, cardanol and cardols in smaller quantities and the CNSL obtained by the hot oil process is entitled "technical CNSL", due to the decarboxylation of the anacardic acid and subsequent formation of cardanol [21-23].

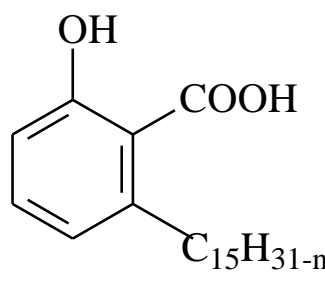

anacardic acid

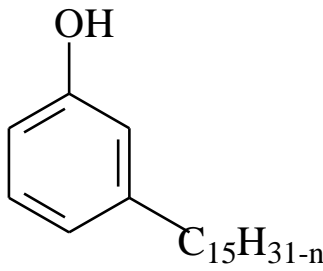

cardanol

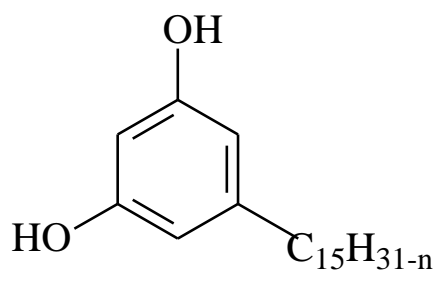

cardol

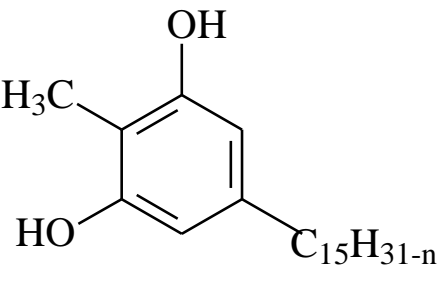

2-methylcardol

$\mathrm{n}=0,2,4,6$

Figure 1: Chemical structures of CNSL constituents.

Therefore, considering the great importance of this group of molecules and their potentiality for the development of new eco-friendly compounds, the present study shows the investigation of the thermal and oxidative stability, and antioxidant effectiveness of a phosphorus compound derived from the main constituent of technical CNSL: the cardanol. This constituent after catalytic hydrogenation (3-n-pentadecylphenol or hydrogenated cardanol) was used as raw material of this investigation. For evaluation of the thermal properties, the authors used thermal analysis (TG-DTG, DSC and DTA) in different atmospheres [14]. Lubricant oil (naphthenic lube base oil) was used as organic substrate to study the antioxidant activity of the obtained phosphorus [24-26]. To study the antioxidant activity of the phosphorus compounds, the researchers used a lubricant oil as organic substrate (naphthenic lube base oil).

\section{MATERIAL AND METHODS}

\section{Material}

The hydrogenated cardanol (HC) was obtained by catalytic hydrogenation method $[27,28]$ and was purified by column chromatography (silica gel) employing hexane as eluent [27, 29]. After purified, the $\mathrm{HC}$ was alkylated by Friedel Crafts mechanism using tert-butyl chloride in the presence of zinc chloride (Lewis acid), obtaining hydrogenated alkylated cardanol.

The hydrogenated alkylated cardanol was phosphorated by nucleophilic substitution ( $\mathrm{Sn} 2)$, using sodium hydroxide and diethyl chlorophosphate, generating an alkyl phosphate. The syntheses and chemical characterizations of the hydrogenated alkylated cardanol and their derivatives were described in the previous work of our group [13, 27, 28]. Petrobras (Brazilian Oil Company, Brazil) supplied the lubricant oil with no further distillation procedure and without additive and the Aldrich Chemical Company supplied the reagents and solvents (analytical grade). 


\section{Physical measurements}

NMR $\left({ }^{1} \mathrm{H},{ }^{13} \mathrm{C}\right.$ and $\left.{ }^{31} \mathrm{P}\right)$ spectra were recorded by AVANCE DRX 500 BRUKER spectrometer, at a frequency of $500 \mathrm{MHz}$ under the following conditions: solvent, $\mathrm{CDCl}_{3}$; tetramethylsilane (TMS) as an internal standard for ${ }^{1} \mathrm{H}$ and ${ }^{13} \mathrm{C}$, and phosphoric acid $\left(\mathrm{H}_{3} \mathrm{PO}_{4}\right)$ for $31 \mathrm{P}$.

FTIR spectra were obtained by use of a FTIR spectrophotometer Shimadzu, model 8300.

The TG-DTG curves were obtained using a SHIMADZU TGA-50H, in synthetic air and nitrogen atmospheres, with a flow of $50 \mathrm{~mL} \cdot \mathrm{min}^{-1}$, sample mass of approximately $10 \mathrm{mg}$, heating rate of $10^{\circ} \mathrm{Cmin}^{-1}$ and temperature range of $25-800{ }^{\circ} \mathrm{C}$. The DSC curves were carried out using a DIFERENTIAL SCANNING CALORIMETER 2920 TA instruments, in nitrogen atmosphere, with a flow of $50 \mathrm{~mL} \cdot \mathrm{min}-1$, sample mass of approximately $10 \mathrm{mg}$, heating rate of $10{ }^{\circ} \mathrm{C} \cdot \mathrm{min}^{-1}$, and temperature range of $25-500{ }^{\circ} \mathrm{C}$. DTA curves were obtained using a SHIMADZU DTA$50 \mathrm{H}$, in synthetic air atmosphere, with a flow of $50 \mathrm{~mL} \cdot \mathrm{min}^{-1}$, sample mass of approximately $10 \mathrm{mg}$, heating rate of $10^{\circ} \mathrm{C} \cdot \mathrm{min}^{-1}$ and temperature range of $25-800{ }^{\circ} \mathrm{C}$. Extrapolated scale $(1 \mathrm{~g})$ decomposition was carried out in a stove at a fixed temperature of $120{ }^{\circ} \mathrm{C}\left( \pm 2{ }^{\circ} \mathrm{C}\right)$ under air atmosphere; after five hours, a sample was removed for analysis by infrared spectroscopy.

\section{Methods}

\section{Synthesis of hydrogenated alkylated cardanol}

Hydrogenated alkylated cardanol was synthesized by the alkylation of hydrogenated cardanol (HC) $(3.3 \mathrm{mmol})$ with tert-butyl chloride $(3.3 \mathrm{mmol})$ in the presence of Lewis acid (zinc chloride), according to the methodology presented in previous work [13, 29, 30].

\section{Synthesis of phosphorus cardanol}

The phosphorus cardanol was synthesized by nucleophilic substitution (Sn2). The stoichiometry ratio of the reaction system was of $1.0 \mathrm{~mol}$ of HC: $1.0 \mathrm{~mol}$ of sodium hydroxide: $1.0 \mathrm{~mol}$ of diethyl chlorophosphate, respectively. The reagents were dissolved in chloroform (30 $\mathrm{mL})$, and the mixture was heated under the reflux system with constant agitation at $60{ }^{\circ} \mathrm{C}\left( \pm 1{ }^{\circ} \mathrm{C}\right)$ for two hours and thirty minutes. After the reaction time, was obtained a viscous yellow oil [27]. After synthesis and purification, the alkyl phosphate was characterized using NMR 13C and 31P, TG-DTG and DSC [4, 13, 27, 30].

\section{Characterization of phosphorus cardanol $-\operatorname{NMR}\left({ }^{1} \mathrm{H},{ }^{13} \mathrm{C}\right.$ and $\left.{ }^{31} \mathrm{P}\right)$}

Physical state: viscous yellow oil. The analysis by ${ }^{1} \mathrm{H}$ NMR, showed the following, (500 MHz, $\left.\mathrm{CDCl}_{3}\right): 0.87\left(\mathrm{t}, 3 \mathrm{H},-\mathrm{CH}_{2}-\left(\mathrm{CH}_{2}\right)_{12}-\mathrm{CH}_{3}\right) ; 1.29\left(\mathrm{t}, 6 \mathrm{H},\left(-\mathrm{O}-\mathrm{CH}_{2} \mathrm{CH}_{3}\right)_{2}\right) ; 1.32\left(\mathrm{~m}, 24 \mathrm{H},-\left(\mathrm{CH}_{2}\right)_{\mathrm{n}}-\right)$; 1.42 (s, 9H, $\left.-\left(\mathrm{CH}_{3}\right)_{3}\right) ; 2.55$ (t, $\left.2 \mathrm{H},-\mathrm{CH}_{2}-\mathrm{Ar}\right) ; 4.23\left(\mathrm{q}, 4 \mathrm{H},\left(-\mathrm{O}^{-} \mathrm{CH}_{2} \mathrm{CH}_{3}\right)_{2}\right) ; 6.87(\mathrm{~d}, 1 \mathrm{H}, \mathrm{Ar}-\mathrm{H})$; 7.22 (d, 1H, Ar-H); 7.29 (s, 1H, Ar-H).

$13 \mathrm{C}\{1 \mathrm{H}\} \mathrm{NMR}$, showed the following, $\left(500 \mathrm{MHz}, \mathrm{CDCl}_{3}\right)$ : $14.16\left(1 \mathrm{C},-\mathrm{CH}_{2}-\left(\mathrm{CH}_{2}\right)_{12}-\mathrm{CH}_{3}\right)$; $16.1\left(2 \mathrm{C},\left(-\mathrm{O}-\mathrm{CH}_{2} \mathrm{CH}_{3}\right)_{2}\right) ; 34.4\left(3 \mathrm{C},-\left(\mathrm{CH}_{3}\right)_{3}\right) ; 52.9\left(1 \mathrm{C},-\mathrm{C}\left(\mathrm{CH}_{3}\right)_{3}\right) ; 64.3\left(2 \mathrm{C},\left(-\mathrm{O}_{-}-\mathrm{CH}_{2} \mathrm{CH}_{3}\right)_{2}\right)$; 119.2 (1C, Ar-C3), 124.1 (1C, Ar-C4), 127.1 (1C, Ar-C6), 136.5 (1C, Ar-C5), 142.3 (1C, Ar-C2), 150.0 (1C, Ar-C1), in accordance with the literature data (Rios (2008), Silverstein et al. (2005)). $31 \mathrm{P}\{1 \mathrm{H}\}$ NMR $\left(500 \mathrm{MHz}, \mathrm{CDCl}_{3}\right):-5.570\left(\mathrm{~s}, 1 \mathrm{P}, \mathrm{O}=\mathrm{P}-(\mathrm{OR})_{3}\right)$, Figure 2, in accordance with the literature data $[27,28,30,31]$. 


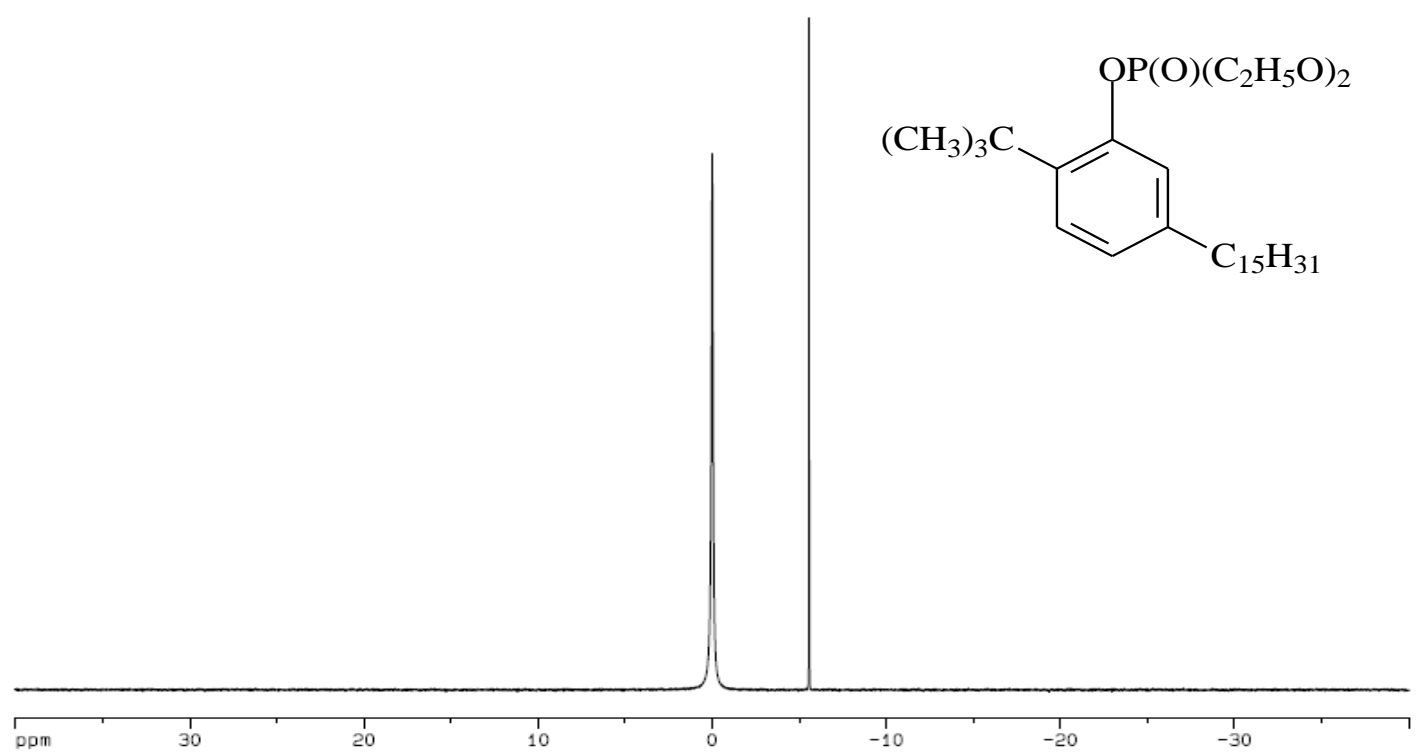

Figure 2: 31P $\{1 \mathrm{H}\} \mathrm{NMR}\left(500 \mathrm{MHz}, \mathrm{CDCl}_{3}\right)$, phosphorus cardanol.

\section{RESULTS AND DISCUSSION}

Thermal and oxidative analyses of phosphorus cardanol

The thermo-oxidative analyses of the phosphorus cardanol were verified with basis of the results of thermogravimetry and differential scanning calorimetry, which gave details concerning thermal behavior of the sample in the presence of different atmospheres. Figures 3 (a) and (b) show the TG-DTG curves, these curves showed the amount of highly volatile matter, medium volatile matter, combustible material and the residual mass remaining after the heating [32]. In this procedure was used a constant rate of $10.0{ }^{\circ} \mathrm{C} \cdot \mathrm{min}^{-1}$. Table 1 gives details of the thermal and oxidative behavior based on the start temperature, final temperature, loss of mass and residual mass remaining after the heating (ash or nonvolatile matter) [33-36]. 


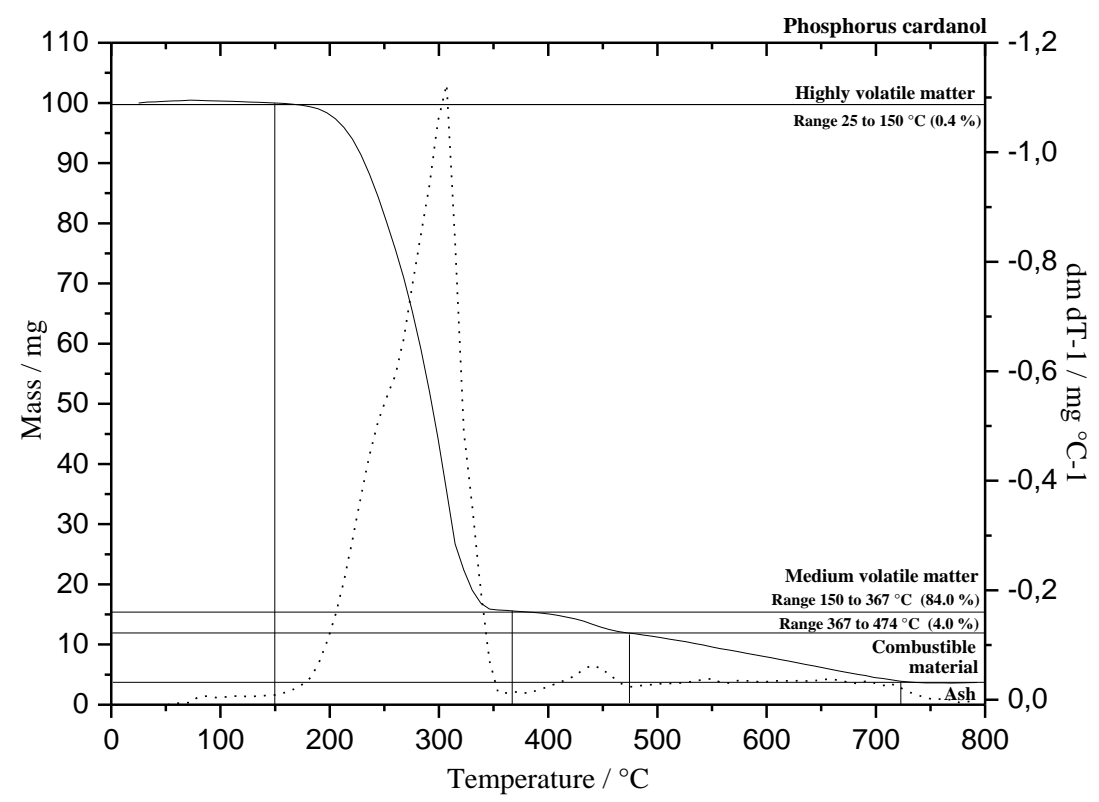

(a)

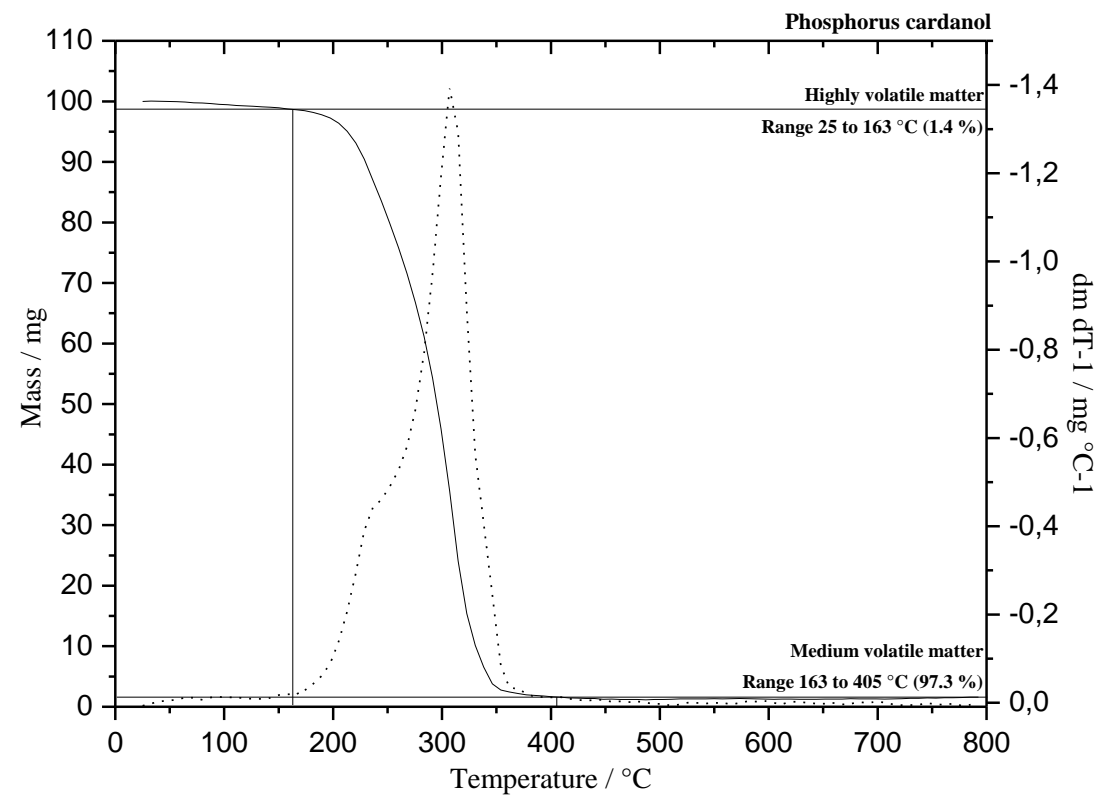

(b)

Figure 3: (a) TG-DTG curves of phosphorus cardanol, air atmosphere and (b) TG-DTG curves of phosphorus cardanol, nitrogen atmosphere. 
Table 1: Thermal and oxidative data of phosphorus cardanol.

\begin{tabular}{|c|c|c|c|c|c|}
\hline Sample & Atmosphere & Component & $\begin{array}{c}\text { Start } \\
\text { Temperature } /{ }^{\circ} \mathrm{C}\end{array}$ & $\begin{array}{c}\text { Final } \\
\text { Temperature } /{ }^{\circ} \mathrm{C}\end{array}$ & Mass/\% \\
\hline \multirow{8}{*}{$\begin{array}{l}\text { Phosphorus } \\
\text { cardanol }\end{array}$} & \multirow{5}{*}{ Air } & Highly volatile & 25 & 150 & 0.4 \\
\hline & & \multirow{2}{*}{$\begin{array}{l}\text { Medium } \\
\text { volatile }\end{array}$} & 150 & 367 & 84.0 \\
\hline & & & 367 & 474 & 4.0 \\
\hline & & Combustible & 474 & 723 & 8.2 \\
\hline & & Ash & 723 & 800 & 3.4 \\
\hline & \multirow{3}{*}{ Nitrogen } & Highly volatile & 25 & 163 & 1.4 \\
\hline & & $\begin{array}{l}\text { Medium } \\
\text { volatile }\end{array}$ & 163 & 405 & 97.3 \\
\hline & & Nonvolatile & 405 & 800 & 1.3 \\
\hline
\end{tabular}

According to results, the phosphorus cardanol showed a thermal behavior compatible with commercial phosphorus compounds, for example triaryl phosphate and diphenyl phosphate, which present mass losses starting at $150{ }^{\circ} \mathrm{C}$ [37]. The stable behavior that phosphorus compounds show can be attributed to the high stability of the P-O-C bond [9, 38]. Therefore, the obtained results suggest the possibility of application of these compounds as antioxidants for lubricant oils, once the degradation of these petrochemical products, in general, starts at $91{ }^{\circ} \mathrm{C}$ [4]. As the phosphate esters find use in a variety of commercial applications (lubricants, hydraulic fluids, polymers and others), and some of these systems may be contaminated by solids and/or metals, water, engine oils, solvents and oxygen; it is very important know their thermal behaviors, once that degradation can be a limiting factor of the application of these phosphorus compounds [39-42].

Based on the evidences reported in the literature, four mechanisms can contribute to the degradation of alkyl and aryl phosphate esters, depending of the environmental conditions to which the compound is exposed [37, 40]. In the case of phosphate esters, all decomposition pathways produce 'strong' acids (phosphoric acid derivatives) as the main degradation product, normally as result of hydrolysis and oxidation (see Figure 5). In lubrication systems, this step is followed by reaction of the acid with the metals components to form metal soaps that cause an increase of oxidation of the lubricant, more acid and higher levels of metal soaps [40, 41, 42]. Therefore, the information on thermal behavior of phosphate esters has significant practical importance. Data of this type can be used for assessment of product life, stability, and quality control, and for design and synthesis of phosphate esters to meet new or existing requirements [41].

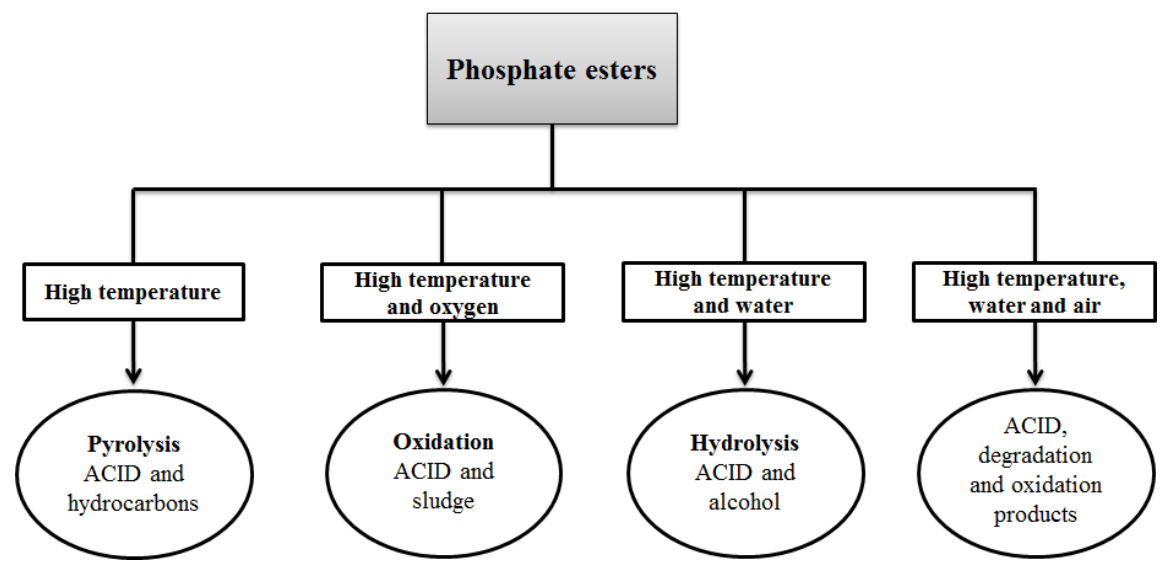

Figure 5: Some possible decomposition pathways for phosphate esters (Adapted from Exxon Technical Bulletin). 
Differential scanning calorimetry (DSC) was used to study the thermal properties of the phosphorus cardanol, see Figure 6. In this procedure was used a constant rate of $10.0{ }^{\circ} \mathrm{C} \cdot \mathrm{min}^{-1}$. DSC curve showed two endothermic peaks probably due to the volatility/thermal degradation of phosphorus compound. The curve exhibited the first onset temperature at $311{ }^{\circ} \mathrm{C}$, reflecting the good thermal stability of the sample. The other step, probably, is involved with thermal degradation process of the phosphorus cardanol [29, 41].

In this work, the authors included the thermal study of the phosphorus cardanol using the heating on a stove. The changes were monitored by FTIR. The infrared spectra of the organophosphate before and after heating in stove are displayed in Figure 7. The spectra contain $\mathrm{C}-\mathrm{O}$ absorption at $1273 / \mathrm{cm}^{-1}, \mathrm{P}-\mathrm{O}-\mathrm{CH}_{2}-\mathrm{CH}_{3}$ absorption at $1158 / \mathrm{cm}^{-1},(\mathrm{RO})_{3} \mathrm{P}=\mathrm{O}$ absorption at $1027 / \mathrm{cm}^{-1}, \mathrm{P}-\mathrm{O}-\mathrm{C}_{6} \mathrm{H}_{5}$ absorption at $982 / \mathrm{cm}^{-1}$ and $\mathrm{P}-\mathrm{O}-\mathrm{CH}_{2}-\mathrm{CH}_{3}$ absorption at $823 / \mathrm{cm}^{-1}$. According to results, it is clear from the infrared spectra that, no changes were observed before and after heating in stove at $120^{\circ} \mathrm{C}\left( \pm 2{ }^{\circ} \mathrm{C}\right)$, under air atmosphere. Therefore, degradation products, if any, are present in small amounts under this condition. This result is in accordance with literature, once that some authors related that, the thermal degradation of phosphate esters only becomes significant at very high temperatures (above $150^{\circ} \mathrm{C}$ ) $[29,38,40-42]$.



Figure 6: DSC curves of phosphorus cardanol, nitrogen atmosphere.



Figure 7 - FTIR of phosphorus cardanol after and before heating. 


\section{Antioxidant effectiveness of phosphorus cardanol}

For evaluation of antioxidant, potential of the phosphorus cardanol the Differential Thermal Analysis (DTA) was used (see Figure 8). This technique permits the prediction of the Initial Decomposition Temperature - IDT (It is reported as the temperature of a sudden increase in the rate of oxidation), which precedes the main oxidation process. The existence of the reactions occurring during the IDT is not detected by the experimental technique used so that seemingly no reaction takes place. In fact, IDT is a preparatory stage in which the entities needed for the full development of auto-oxidation are formed. The high IDT is considered a relative measure of the stability of materials [39].

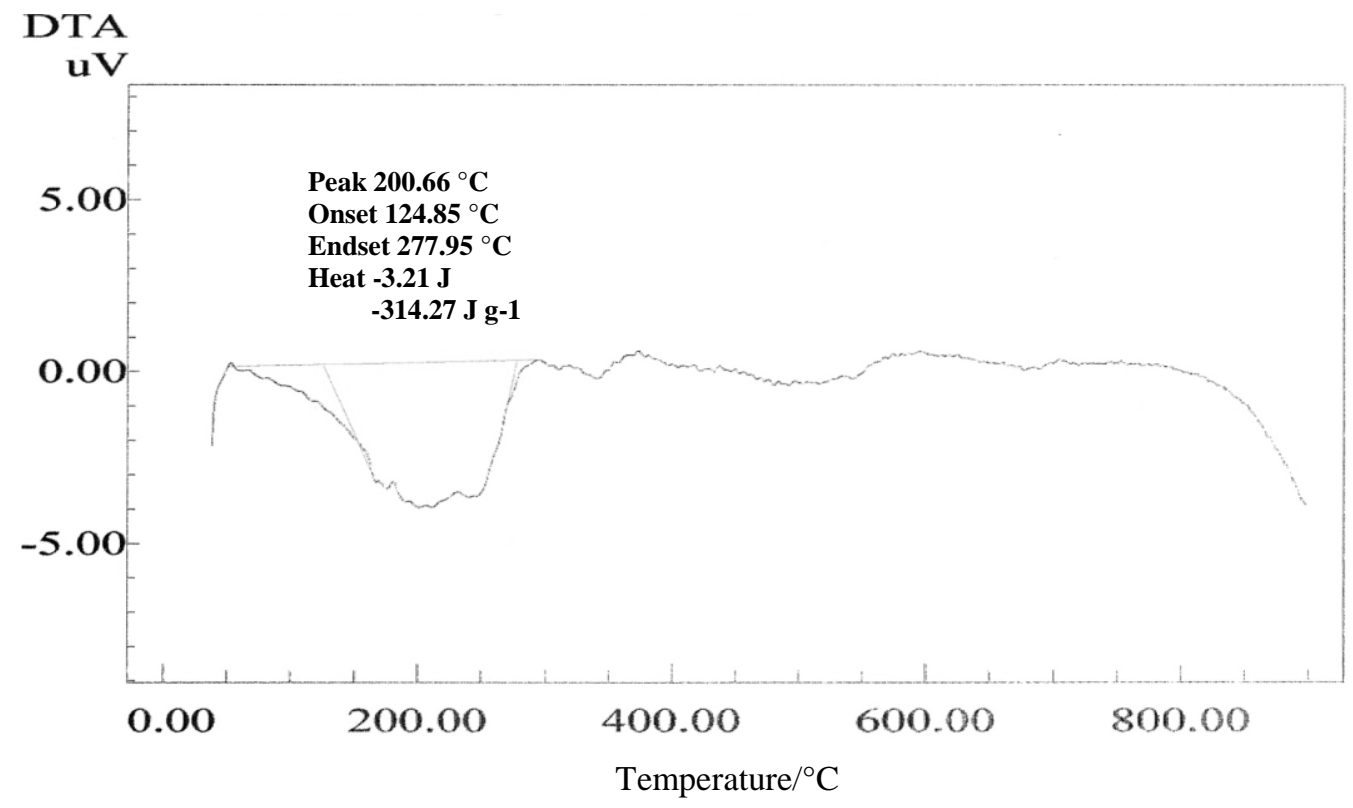

Figure 8: DTA curve of naphthenic lube base oil + 1\% phosphorus cardanol, air atmosphere.

The parameters obtained by DTA measurements are given in Table 2. According to results, antioxidant effectiveness of phosphorus cardanol was verified by the difference between initial decomposition temperature (IDT) for lubricant oil $\left(91.28{ }^{\circ} \mathrm{C}\right)$ and the sample: lubricant oil $+1.0 \%$ phosphorus cardanol $\left(124.85{ }^{\circ} \mathrm{C}\right)$. Table 2 also shows the decrease of energy involved in the oxidation process of the lubricant oil $\left(\Delta \mathrm{H} / \mathrm{J}^{-1} \mathrm{~g}^{-1}\right)$, in the presence of the phosphorus cardanol [29, 36]. DTA has been used to study of oxidation processes because, endothermic and exothermic peaks observed in this technique, in inert and oxidative atmosphere, gives additional information about the degradation process.

Table 2: DTA measurements describing antioxidant effectiveness of phosphorus cardanol.

\begin{tabular}{l|c|c|c}
\hline \multicolumn{1}{c|}{ Sample } & IDT ${ }^{\boldsymbol{a}} /{ }^{\circ} \mathbf{C}$ & $\mathbf{T}_{\max }{ }^{\boldsymbol{b}} /{ }^{\circ} \mathbf{C}$ & \multirow{2}{*}{$\boldsymbol{\Delta} \mathbf{H} / \mathbf{J ~ g ~}^{-\mathbf{c}}$} \\
\cline { 2 - 3 } & $\mathbf{A i r}$ & $\mathbf{A i r}$ & \\
\hline Lubricant oil & 91.28 & 225.75 & -952.80 \\
\hline Lubricant oil + 1,0 \% phosphorus cardanol & 124.85 & 220.66 & -314.27 \\
\hline${ }^{a}$ Initial Decomposition Temperature & & \\
${ }^{b}$ Temperature of maximum degradation rate \\
${ }^{c}$ Energy involved in oxidation process
\end{tabular}




\section{CONCLUSION}

The phosphorus compound derived from hydrogenated cardanol was characterized using spectroscopy and thermal analyses. The phosphorus cardanol displayed a good thermal stability, mainly when compared with to the commercial products of the same class. Hence, according to the results, the organophosphate derived from biomass (CNSL) comes as a promising ecofriendly antioxidant, for the petrochemical industry, being in consonance with green chemistry.

\section{ACKNOWLEDGEMENTS}

The authors acknowledge Petroleo Brasileiro S.A. (PETROBRAS) and CNPq (Process number 406697/2013-2) for the financial support, the Organic and Inorganic Chemistry Department of Federal University of Ceará by chemical and thermal analyses, and the Northeastern Center of Application and Use of Nuclear Magnetic Resonance - CENAUREM/UFC by 1H, 13C and 31P NMR.

\section{REFERENCES}

1. Maia FJN, Ribeiro VGP, Lomonaco D, Luna FMT, Mazzetto SE. Synthesis of a new thiophosphorylated compound derived from cashew nut shell liquid and study of its antioxidant activity. Ind Crop Prod. 2012 36(1): 271-5, doi:10.1016/j.indcrop.2011.10.019.

2. Maia FJN, Ribeiro VGP, Clemente CS, Lomonaco D, Vasconcelos PHM, Mazzetto SE. Thermooxidative evaluation of new cardol derivatives as antioxidants for mineral oils. J Therm Anal Calorim. 2012 109:1013-18, doi: 10.1007/s10973-011-1870-5.

3. Patel RN, Bandyopadhyay S, Ganesh A. Extraction of cashew (Anacardium occidentale) nut shell liquid using supercritical carbon dioxide. Bioresour Technol. 2006 97(6): 847-53, doi: 10.1016/j.biortech.2005.04.009.

4. Rios MAF, Mazzetto SE, Carioca JOB, Barros GG. Evaluation of antioxidant properties of a phosphorated cardanol compound on mineral oils (NH10 and NH20). Fuel 2007 86(15): 2416-21, doi: 10.1016/j.fuel.2007.01.034 .

5. Rwei SP, Liu ML. Synthesis of high performance phosphorine antioxidants and their application to mCOC. Fiber Polym. 2008 9(1):1-6, doi: 10.1007/s12221-008-0001-9.

6. Kirpichnikov PA, Mukmeneva NA, Pobedimskii DG. Organophosphorus Stabilisers of Polymers: Efficiency and the Mechanisms of Action. Russ Chem Rev. 1983, 52: 1051-63.

7. Lochab B, Varma IK, Bijwe J. Cardanol-based bisbenzoxazines: Effect of structure on thermal behaviour. J Therm Anal Calorim. 2012 107(2): 661-8, doi: 10.1007/s10973-011-1854-5.

8. Lochab B, Varma IK, Bijwe J. Thermal behaviour of cardanol-based benzoxazines Monomers and polymers. J Therm Anal Calorim. 2010 102: 769-774, doi: 10.1007/s10973-010-0736-6.

9. Menon ARR, Pillai CKS, Nando GB. Vulcanization of natural rubber modified with cashew nut shell liquid and its phosphorylated derivative — a comparative study. Polymer. 1998 39(17): 403336, doi: 10.1016/S0032-3861(97)00539-9.

10. Rodrigues FHA, Feitosa JPA, Ricardo NMPS, França FCF, Carioca JOB. Antioxidant activity of cashew nut shell liquid (CNSL) derivatives on the thermal oxidation of synthetic cis-1,4polyisoprene. J Braz Chem Soc. 2006 17(2): 265-71, doi: 10.1590/S0103-50532006000200008.

11. Reddy VA, Gedam PH, Sampathkumaran PS. Effect of oil length of alkyd on the physicochemical properties of its coatings. Prog Org Coat. 1986 14(1): 87-97, doi: 10.1016/00330655(86)80017-6.

12. Short EL, Tychopoulos V, Tyman JPH. Long chain phenols - part 30: A rate study of the mannich reaction of phenols (with particular reference to 3-pentadecylphenol). J Chem Technol Biotechnol. 2006 53(4): 389-96, doi: $10.1002 /$ jctb.280530412.

13. Rios MAS, Sales FAM, Mazzetto SE. Study of Antioxidant Properties of 5-n-Pentadecyl-2-tertamylphenol. Energy Fuels. 2009 23(5): 2517-22, doi: 10.1021/ef800994j.

14. Rios MAS, Mazzetto SE. Effect of organophosphate antioxidant on the thermo-oxidative degradation of a mineral oil. J Therm Anal Calorim. 2013 111(1): 553-9, doi: 10.1007/s10973011-2160-y.

15. Kim S. The reduction of formaldehyde and VOCs emission from wood-based flooring by green adhesive using cashew nut shell liquid (CNSL). J Hazard Mater. 2010 182: 919-22, doi: 10.1016/j.jhazmat.2010.03.003. 
16. Lopes AAS, Carneiro EA, Mazzetto SE, Rios MAS, Carioca JOB, Filho JJH, Barros GG. Study of antioxidant property of a thiosphorated compound derived from cashew nut shell liquid in hydrogenated naphthenics oils. Braz J Chem Eng. 2008 25(1): 119-27, doi: 10.1590/S010466322008000100013.

17. Orazio AA, Stefano B, Cinzia F, Paolino F, Giuseppe M, Raffaele S. Synthesis and reactions of nitro derivatives of hydrogenated cardanol. Tetrahedron. 2006 62(25): 6113-20, doi: 10.1016/j.tet.2006.03.105.

18. Puangmale S, Petsom A, Thamyongkit P. A porphyrin derivative from cardanol as a diesel fluorescent marker. Dyes Pigments. 2009 82(1): 26-30, doi: 10.1016/j.dyepig.2008.10.015.

19. Mele G, Jun L, Margapoti E, Martina F, Vasapollo G. Synthesis of novel porphyrins cardanol based via cross metathesis. Catal Today. 2009 140: 37-43, doi: 10.1016/j.cattod.2008.07.006.

20. Trevisan MTS, Pfundstein B, Haubner R, Würtele G, Spiegelhalder B, Bartsch H. Characterization of alkyl phenols in cashew (Anacardium occidentale) products and assay of their antioxidant capacity. Food ChemToxicol. 2006 44(2): 188-97, doi: 10.1016/j.fct.2005.06.012.

21. Philip JY, Da Cruz Francisco J, Dey ES, Buchweishaija J, Mkayula LL, Ye L. Isolation of Anacardic Acid from Natural Cashew Nut Shell Liquid (CNSL) Using Supercritical Carbon Dioxide. J Agric Food Chem. 2008 56(20): 9350-4, doi: 10.1021/jf801532a.

22. Tocco G, Fais A, Meli G, Begala M, Podda G, Fadda MB, Corda M, Attanasi OA, Filippone P, Beretta S. PEG-immobilization of cardol and soluble polymer-supported synthesis of some cardol-coumarin derivatives: Preliminary evaluation of their inhibitory activity on mushroom tyrosinase. Bioorg Med Chem Lett. 2009 19(1): 36-9, doi: 10.1016/j.bmcl.2008.11.020.

23. Tyman JHP, Johnson RA. Synthesis and Antioxidancy of Some n-Alkyl, t-Alkyl, Homologous and Isomeric Lipidic Alkylthiobisphenols. J Am Oil Chem Soc. 2007 84(6): 573-78, doi: 10.1007/s11746-007-1060-6.

24. Pfaendtner J, Broadbelt LJ. Mechanistic Modeling of Lubricant Degradation. 1. Structure-Reactivity Relationships for Free-Radical Oxidation. Ind Eng Chem Res. 2008 47(9): 2886-96, doi: 10.1021/ie0714807.

25. Koh CS, Butt JB. Experimental and Modeling Study of Kinetics and Selectivity in the Oxidation of a Poly (.alpha.-olefin) Lubricant. Ind Eng Chem Res. 1995 34(2): 524-35, doi: 10.1021/ie00041a013.

26. Neto RCR, Lima DO, Pinheiro TDS, Almeida RF, Dantas TNC, Dantas MSG, Araújo MAS, Júnior CLC, Azevedo DCS. Thermo-Oxidative Stability of Mineral Naphthenic Insulating Oils: Combined Effect of Antioxidants and Metal Passivator. Ind Eng Chem Res. 2004 43(23): 7428-34, doi: 10.1021/ie049645o.

27. Rios MAF. Síntese e Aplicabilidade de Antioxidantes derivados do Cardanol hidrogenado. M.S. Thesis, Organic and Inorganic Chemical Department, Federal University of Ceará, Brazil, 2008.

28. Rios MAS, Mazzetto SE. Procedimentos de Preparação de Aditivos Organofosforados obtidos da Modificação Química do 3-n-pentadecilfenol para Aplicação nos Setores Industriais. 2008 PI0801708-5A2.

29. Rios MAS, Santiago SN, Lopes AAS, Mazzetto SE. Antioxidative Activity of 5-n-Pentadecyl-2tert-butylphenol Stabilizers in Mineral Lubricant Oil. Energy Fuels. 2010 24(5): 3285-91, doi: 10.1021/ef100262j.

30. Rios MAS, Mazzetto SE. Thermal behavior of phosphorus derivatives of hydrogenated cardanol. Fuel Process Technol. 2012 96: 1-8, doi: 10.1016/j.fuproc.2011.12.004.

31. Silverstein RM, Webster FX, Kiemle DJ. Spectrometric Identification of Organic Compounds. 7th ed., John Wiley \& Sons, New York, 2005.

32. ASTM E1131-08, Composition Analysis by Thermogravimetry, 2008.

33. Bernal C, Couto AB, Breviglieri ST, Cavalheiro ET. Influência de alguns parâmetros experimentais nos resultados de análises calorimétricas diferenciais - DSC. Quim Nova. 2002 25(5): 849-55, doi: 10.1590/S0100-40422002000500023.

34. Cavalheiro ETG, Ionashiro M, Breviglieri ST, Marino G, Chierice GO. A Influência de Fatores Experimentais nos Resultados de Análises Termogravimétricas. Quim Nova. 1995 18(3): 305-8.

35. Doyle CD. Estimating Thermal Stability of Experimental Polymers by Empirical Thermogravimetric. Analysis Anal Chem. 1961 33(1): 77-9, doi: 10.1021/ac60169a022.

36. Wendlandt WW. Thermal Methods of Analysis, John Wiley \& Sons, New York, 1964.

37. Exxon Mobil Corporation - Technical Bulletin, "Stability of Phosphate Ester Aviation Hydraulic Fluids", 2008.

38. Howell BA, Al-Omari M. Thermal and spectroscopic characterization of a triaryl phosphate hydraulic fluid. J Therm Anal Calorim. 2012 109(3): 1157-61, doi: 10.1007/s10973-012-2518-9. 
39. Hamciuc C, Vlad-Bubulac T, Petreus O, Lisa G. Kinetics of thermal degradation in non-isothermal conditions of some phosphorus-containing polyesters and polyesterimides. Eur Polym J. 2007 43(3): 980-8, doi: 10.1016/j.eurpolymj.2006.12.018.

40. Phillips WD. The high-temperature degradation of hydraulic oils and fluids. J Synth Lubrication. 2006 23: 39-70, doi: 10.1002/jsl.11.

41. Shankwalkar SG, Cruz C. Thermal Degradation and Weight Loss Characteristics of Commercial Phosphate Esters. Ind Eng Chem Res. 1994 33(3): 740-3, doi: 10.1021/ie00027a038.

42. Shankwalkar SG, Placek D. Oxidation and Weight Loss Characteristics of Commercial Phosphate Esters. Ind Eng Chem Res. 1992 31(7): 1810-13, doi: 10.1021/ie00007a029. 